\title{
Tolerance to Salinity of Sesame Genotypes in Different Phenological Stages
}

\author{
Janivan Fernandes Suassuna1, Pedro Dantas Fernandes ${ }^{2 *}$, Marcos Eric Barbosa Brito ${ }^{3}$, \\ Nair Helena Castro Arriel ${ }^{4}$, Alberto Soares de Melo ${ }^{1}$, Josely Dantas Fernandes ${ }^{5}$
}

\author{
${ }^{1}$ Department of Biology, State University of Paraiba, UEPB, Campina Grande, Brazil \\ ${ }^{2}$ Department of Agricultural Engineering, Federal University of Campina Grande, UFCG, Campina Grande, Brazil \\ ${ }^{3}$ Department of Agricultural Science, Federal University of Campina Grande, UFCG, Pombal, Brazil \\ ${ }^{4}$ Embrapa-Brazilian Agricultural Research Corporation, Campina Grande, Brazil \\ ${ }^{5}$ Department of Agrobiology and Agriculture, State University of Paraiba, UEPB, Lagoa Seca, Brazil \\ Email: *pedrodantasfernandes@gmail.com, jf.su@hotmail.com, marcosericbb@yahoo.com.br, nair.arriel@embrapa.br, \\ alberto@uepb.edu.br, joselysolo@yahoo.com.br
}

How to cite this paper: Suassuna, J.F., Fernandes, P.D., Brito, M.E.B., Arriel, N.H.C., de Melo, A.S. and Fernandes, J.D. (2017) Tolerance to Salinity of Sesame Genotypes in Different Phenological Stages. American Journal of Plant Sciences, 8, 1904-1920. https://doi.org/10.4236/ajps.2017.88129

Received: June 20, 2017

Accepted: July 21, 2017

Published: July 24, 2017

Copyright $\odot 2017$ by authors and Scientific Research Publishing Inc. This work is licensed under the Creative Commons Attribution International License (CC BY 4.0).

http://creativecommons.org/licenses/by/4.0/

\begin{abstract}
The sesame crop is usually avoided in salt-affected areas because of the various effects of saline stress on plants. Besides varying between species, salinity effects are known to vary for genotypes of the same species as well as plant development stages. Thus, through the irrigation of plants with saline water, this study evaluates tolerance to saline stress of new sesame genotypes in different phenological stages. Three experiments were carried out under greenhouse conditions, using the sesame genotypes BRS Seda, LAG-927561 and LAG-26514. Water with different levels of electrical conductivity $(\mathrm{ECw}=0.6,1.6,2.6,3.6$ and $4.6 \mathrm{dS}$ $\mathrm{m}^{-1}$ ) was used to irrigate plants during germination and initial growth stages, as well as the entire crop cycle. Tolerance to saline stress $\left(3.6 \mathrm{dS} \mathrm{m}^{-1}\right)$ during growth and production stages was also studied. Salinity did not affect sesame germination, but seedling growth was hindered from the ECw of $1.6 \mathrm{dS} \mathrm{m}$ onwards, and plant height was the most affected growth variable. Seed production is affected by salinity, regardless of the phenological stage in which plants are exposed to salinity. The strains LAG-927561 and LAG-26514 show promising signs in studies on adaptation to saline stress.
\end{abstract}

\section{Keywords}

Sesamum indicum, Development Stages, Saline Stress, Relative Crop Yield

\section{Introduction}

The sesame crop (Sesamum indicum L.) has stood out among oilseed plants due to the commercial importance of its seeds, their fresh consumption, the food 
industry and oil production. Rich in antioxidants, sesame oil is also notable for its resistance to oxidation, which is higher than in other species [1] [2].

Sesame is the earliest oilseed plant to be used by humans [3]. Adapted to tropical climates and with low water demand, sesame is a good cultivation option for semi-arid regions as it is rich in proteins and can provide an alternative income source, especially for small and medium farmers [4]. When irrigated, according to Uçan and Killi [5] its flowering and production increase linearly with the volume of water applied.

For agricultural production in arid and semi-arid areas, a relevant aspect to be considered is the salinity of soils and water resources, aspects that are common in many regions worldwide [6] [7]. In the Northeast Region of Brazil, for instance, irregular and insufficient rains combined with high evaporation rates during most of the year increase the risks of soil salinization, especially under deficient drainage conditions.

In general, plant capacity to adjust to saline stress varies widely as variation can occur between cultivars using the same species and between phenological stages of the same genotype [6] [8]. Many effects of salinity on sesame have been reported in the literature. Abbasdokht et al. [9] mention sesame as moderately tolerant to saline stress. Many studies report that plants at germination and initial growth stages tolerate higher salinity levels, and variability has been observed between sesame genotypes [9] [10].

Bahrami and Razmjoo [11], studying 10 cultivars, identified 2 genotypes that were tolerant to saline stress during stages of germination and initial seedling growth. Mahmood et al. [12] observed variability between 4 cultivars, and one of them stood out with respect to seed production. According to these authors, plants with high tolerance to saline stress in initial phases can also be more tolerant during adult stage.

It should be pointed out that, in addition of divergent, the results for the effects of salinity on sesame in the available literature are scarce and there is no information on the phenological stage in which plants are most sensitive to salt effects. In this context, this study evaluates the effects of salinity on sesame plants in different development stages in order to identify the genotypes that best adapt to this stress factor.

\section{Material and Methods}

\subsection{Research Location and General Procedures}

Three experiments were carried out under greenhouse conditions in Campina Grande, PB, Brazil ( $7^{\circ} 15^{\prime} 18^{\prime \prime} \mathrm{S} ; 35^{\circ} 52^{\prime} 28^{\prime \prime} \mathrm{O}$; altitude of $550 \mathrm{~m}$ ). The greenhouse was covered with plastic of agricultural use and laterally protected by a fine mesh screen. According to Köppen's classification, the climate of the region is "Csa", with hot, dry summer and rains in the autumn and winter [13].

Two white-seeded sesame genotypes, the variety BRS Seda (Brazil Seeds) and the strain LAG-927561 (LAG-Advanced Sesame Strain, called Branquinha)—and a black-seeded strain LAG-26514, called Pretinha were used for the experiments. 
The Sesame cultivar BRS Seda was obtained through mass selection applied in cv. Zirra FAO 51284, and the advanced strain LAG is originated from the access PI 231034-USDA. In both cases, there was a selection pressure for white seeds. The seeds of the advanced strain LAG-26514 are black in color, originating from the access PI 200109-USDA. The plants of the three genotypes are of medium height and early cycle, with seed oil content between $50 \%$ and $52 \%$. They are recommended for cultivation in sandy soils $(\mathrm{pH}=5,5-7.0)$, with altitude of up to $1250 \mathrm{~m}$, air temperatures between $23^{\circ} \mathrm{C}-30^{\circ} \mathrm{C}$, and pluviosity of $300 \mathrm{~mm}$, well distributed during the cultivation cycle.

The seeds were provided by the Brazilian Agricultural Research Corporation (National Center of Cotton Research), located in Campina Grande, PB. All seeds were collected in the same period, under the same cultural management practices, selected before seeding and treated with a dicarboximide fungicide ( $240 \mathrm{~g}$ per $\mathrm{kg}^{-1}$ of seeds).

Humidity in the substrate was maintained at field capacity during seeding. Three seeds were planted in each recipient at a depth of $1 \mathrm{~cm}$. After seedling emergence, thinning was performed 11 days after seeding (DAS), leaving only one plant per recipient. Throughout all the experimental phase there was control of weeds and insects and diseases.

The treatments varied in each experiment and consisted of different managements of salinity water irrigation according to the phenological phases of the plants. Saline water composition was obtained using the salts $\mathrm{NaCl}, \mathrm{CaCl}_{2} \cdot 2 \mathrm{H}_{2} \mathrm{O}$ and $\mathrm{MgCl}_{2} \cdot 6 \mathrm{H}_{2} \mathrm{O}$, maintaining a proportion of 7:2:1 for $\mathrm{Na}: \mathrm{Ca}: \mathrm{Mg}$. This ratio prevails in water sources used for irrigation in most small farms of Northeast Brazil [14].

\subsection{Experiment 1: Salinity Stress during Germination and Initial Growth}

In this experiment the treatments comprised of 5 levels of electrical conductivity for the irrigation water $\left(\mathrm{ECw}=0.6,1.6,2.6,3.6\right.$ and $4.6 \mathrm{dS} \mathrm{m} \mathrm{m}^{-1}$, at $\left.25^{\circ} \mathrm{C}\right)$, set in a randomized block design, with four replications and 10 evaluated plants in each plot.

Plants were cultivated in $280-\mathrm{mL}$ polyethylene tubes, filled with $300 \mathrm{~g}$ of a commercial humus-based organic compound (70\%), plant residues $(20 \%)$ and cattle manure (10\%). Plants were irrigated daily from 8 to 9 AM with saline water according to the ECw levels of the treatments. The volume of water applied in each irrigation event $(V i)$ was estimated based on the replenishment of the volume consumed in the previous day, ensuring a leaching fraction of $20 \%$ (Equation (1)), in order to maintain part of the salts from the irrigation water accumulated in the root zone. The leached volume was estimated with the aid of recipients placed below the tubes.

$$
V i=\frac{(V a-V d)}{1-L f}
$$

$V i=$ volume to be applied in the next irrigation event $(\mathrm{mL}) ; V a=$ volume ap- 
plied in the irrigation of the previous day $(\mathrm{mL}) ; V d=$ volume drained $(\mathrm{mL})$; and $L f=$ leaf fraction: it was used a coefficient of approximately $20 \%(1-0.20)$.

This experiment lasted until 26 DAS, when a final evaluation was done. The number of seedlings that emerged in each plot was recorded daily in order to evaluate germination percentage (GP) and considered plants that emerged on the surface of the substrate. The germination speed index (GSI) was obtained by measuring the relationship between the number of seedlings that emerged in each plot and the number of days elapsed of the respective count [15].

Plant growth was evaluated at 11 and 26 DAS, based on the variables number of leaves, plant height and stem diameter.

\subsection{Experiment 2: Salinity Stress during the Entire Production Cycle}

The same sesame genotypes were subjected to salinity treatments $(0.6,1.6,2.6$, 3.6 and $4.6 \mathrm{dS} \mathrm{m}^{-1}$ ), but irrigation with saline water started at $29 \mathrm{DAS}$, extending until the end of the cycle in order to evaluate plant production. The experiment was set in a randomized block design, with four replicates and four plants in each plot.

Plants were cultivated in 20-L recipients with drains at the bottom to collect and monitor the volumes of drained water. The pots were filled with one layer of crushed stone $(2 \mathrm{~kg})$ and another of washed sand $(1 \mathrm{~kg})$, covering the bottom. Then, $25 \mathrm{~kg}$ of material from a non-saline, non-sodic soil of sandy loam texture that had been previously sieved and fertilized was added. Also, $600 \mathrm{~g}$ of organic matter (earthworm humus) was added in order to improve the structure and the water retention of the soil material.

Basal fertilization with NPK was performed by incorporating 100, 300 and 150 mg of $\mathrm{N}, \mathrm{P}_{2} \mathrm{O}_{5}$ and $\mathrm{K}_{2} \mathrm{O}$ per $\mathrm{kg}$ of soil, respectively, using ammonium sulfate, single superphosphate and potassium chloride.

Irrigations with non-saline water were performed on alternate days until the application of the saline treatments, which started at 29 DAS. Then, plants were irrigated daily with saline water of ECw levels that corresponded to the treatments. Throughout the cycle, soil water content was kept above $80 \%$ of field capacity, and a leaching fraction of $20 \%$ was applied every 15 days, according to Equation (1).

Top-dressing fertilization was performed via irrigation water, using $50 \mathrm{~kg} \cdot \mathrm{ha}^{-1}$ of $\mathrm{N}$ ( $3 \mathrm{~g}$ of ammonium sulfate per pot), divided into two applications (at 34 and $54 \mathrm{DAS})$ and $20 \mathrm{~kg} \cdot \mathrm{ha}^{-1}$ of $\mathrm{K}_{2} \mathrm{O}(0.41 \mathrm{~g}$ of potassium chloride per pot) at 54 DAS. Foliar fertilization was performed at 54 DAS using a liquid nutritional formulation diluted in water at $1 \%$, which contained the micronutrients $\mathrm{B}(0.5 \%), \mathrm{Cu}$ (0.2\%), Fe (0.10\%), Mn (0.50\%), Mo (0.10\%) and Zn (1.0\%).

Growth parameters (number of leaves, plant height and stem diameter) were measured at 29 and 84 DAS.

For the evaluation of sesame production, the number of capsules per plant (NCP) and the mass of seeds per plant (MSP) were recorded. Capsules were col- 
lected during the typical maturation phase of each genotype and the drying process was completed in the same greenhouse where plants were cultivated, avoiding losses by dehiscence. Seeds were manually removed from the capsules and weighed using precision scales. The humidity was corrected to $10 \%$ in accordance with the criteria used for sesame seed analysis.

The genotypes were classified according to salinity tolerance for each level of ECw tested. The criterion of relative yield was used, which is based on the relative reduction of seed production (g per plant) seen in the treatments (1.6, 2.6, 3.6 and $4.6 \mathrm{dS} \mathrm{m}^{-1}$ ) in relation to the production obtained using low-salinity water $\left(0.6 \mathrm{dS} \mathrm{m}^{-1}\right)$. To classify the genotypes, the following indices of relative reduction of production were adopted, which were adapted from the procedures described in Veatch et al. [16]: <20\%-Tolerant to salinity; $21 \%$ $40 \%$-Moderately tolerant; $41 \%$ - 60\%-Moderately sensitive; and $>60 \%$-Sensitive to salinity.

\subsection{Experiment 3: Salinity Stress in Different Phenological Stages}

The third experiment also encompassed the entire cycle of the three genotypes, which were cultivated in the same type of recipient described previously. Three irrigation managements were studied. The same saline stress method was used but plant phenological stage varied, following the installation procedures described in the experiment above.

Until $10 \mathrm{DAS}$, low-salinity water $\left(\mathrm{ECw}=0.6 \mathrm{dS} \mathrm{m}^{-1}\right)$ was given to all plots. Irrigation managements started, also on alternate days, at varying plant phenological stages: WS-plants without saline stress, irrigated with low-salinity water $\left(0.6 \mathrm{dS} \mathrm{m}^{-1}\right)$ during the entire cycle; SS1-plants under saline stress during the vegetative stage (irrigation with water of $\mathrm{ECw}=3.6 \mathrm{dS} \mathrm{m}^{-1}$ from 11 DAS to flowering); SS2-plants under saline stress in the reproductive stage (irrigation with water of $\mathrm{ECw}=3.6 \mathrm{dS} \mathrm{m}^{-1}$ from flowering to the cycle end). In the other stages, good quality water was used.

Combining all the factors, there were 9 treatments ( 3 genotypes $\times 3$ irrigation managements) set in a randomized block design with four replications and six evaluated plants per plot.

Growth variables (number of leaves, plant height and stem diameter) were measured at 11 and 79 DAS. The number of capsules per plant (NCP) and the mass of seeds per plant (MSP) were obtained in accordance with the procedures adopted in the previous experiment. Furthermore, in each phenological stage the salinity tolerances of the genotypes were classified based on the production loss of plants under no saline stress.

\subsection{Statistical Analysis}

The data from the three experiments were subjected to ANOVA (F test); means of qualitative variables were compared using Tukey's test $(p<0.05$, and $p<0.01)$ and means of quantitative variables were subjected to polynomial regression analysis [17]. 


\section{Results and Discussion}

\subsection{Experiment 1-Germination and Seedling Growth}

Based on ANOVA results, the percentage of germination of the genotypes was not affected by the factors in studies (salt concentrations and genotypes), in isolated action nor in interaction, with mean values of $97.28 \%$ for BRS Seda, $92.84 \%$ for LAG-927561 (Branquinha) and 96.54\% for LAG-26514 (Pretinha) (Table 1). The fact that there is no significant difference between genotypes is evidence of the tolerance of these cultivars to saline stress during this phase.

In the literature, the effects of salinity on sesame seedling germination are controversial: some studies indicate that this is the stage of highest tolerance, but other studies found differences in sensitivity to saline stress between genotypes [10] [11].

In addition, the germination speed index (GSI) was not harmed by irrigation

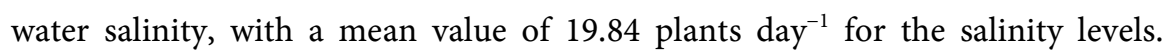
However, the three genotypes differed significantly regarding GSI, an important seed vigor index, with the highest value (23.17 plants day ${ }^{-1}$ ) found for BRS Seda, followed by LAG-26514 (20.31 plants day ${ }^{-1}$ ) and LAG-927561 (16.57 plants day $^{-1}$ ) (Table 1). It should be pointed out that the seeds were collected in the same harvest season and under similar cultural management practices.

AZEVEDO et al. [18] evaluated the effects of $\mathrm{NaCl}$, which varied from 0.0 to $200 \mathrm{mmol}_{\mathrm{c}} \mathrm{L}^{-1}$ of $\mathrm{NaCl}$, on the germination of sesame genotypes and observed a negative influence of salinity on four cultivars (CNPA-G2, INAMAR, Ouro 9171 and IAC-Ouro) from $7.5 \mathrm{dS} \mathrm{m}^{-1}$ of $\mathrm{NaCl}$ onwards. This level is higher than the highest ECw tested in this study $\left(4.6 \mathrm{dS} \mathrm{m}^{-1}\right)$, which explains why the genotypes were not affected. This ECw limit was selected because it is present in the water

Table 1. Germination percentage (GP) and germination speed index (GSI) for sesame genotypes irrigated with saline water during the stages of germination and initial growth.

\begin{tabular}{ccc}
\hline \multirow{2}{*}{ Genotypes } & GP $(\%)$ & GSI \\
\cline { 2 - 3 } & Mean & Mean \\
\hline BRS Seda & $97.2839 \mathrm{a}$ & $23.1677 \mathrm{a}$ \\
LAG-927561 & $92.8395 \mathrm{a}$ & $16.5688 \mathrm{c}$ \\
LAG-26514 & $96.5432 \mathrm{a}$ & $20.3088 \mathrm{~b}$ \\
Salinity $\left(\mathrm{dS} \mathrm{\textrm {m } ^ { - 1 } )}\right.$ & & \\
0.6 & 96.2963 & 20.1407 \\
1.6 & 95.4732 & 20.0944 \\
2.6 & 94.2386 & 20.0463 \\
3.6 & 96.7078 & 19.9703 \\
4.6 & 95.0617 & 18.9240 \\
CV $(\%)$ & 5.84 & 7.95 \\
\hline
\end{tabular}

Means followed by the same letter in the column did not differ for Tukey's test $(p<0.05)$; CV = Coefficient of variation. 
sources of small farms in Brazil's semi-arid region [18].

Salinity significantly influenced plant growth variables but had no effect on the genotypes, either separately or in interaction with the ECw levels. Plant height (Figure 1(a)), stem diameter (Figure 1(b)) and number of leaves (Figure 1 (c)) were reduced by $10.89 \%, 8.69 \%$ and $6.17 \%$, respectively, for each unit increase of salinity $\left(\mathrm{dS} \mathrm{m}^{-1}\right)$ in the irrigation water. The most negative effect occurred for plant height, which had the highest decrease percentage (Figure $1(\mathrm{a}))$.

In general, the use of saline water caused a decrease and delay in the initial growth of sesame plants in this study, which corroborates the results observed by Azevedo et al. [17], Joshi and Panchal [6], and Bazrafshan and Ehsanzadeh [10]. These authors reported harmful effects of salinity on germination and initial

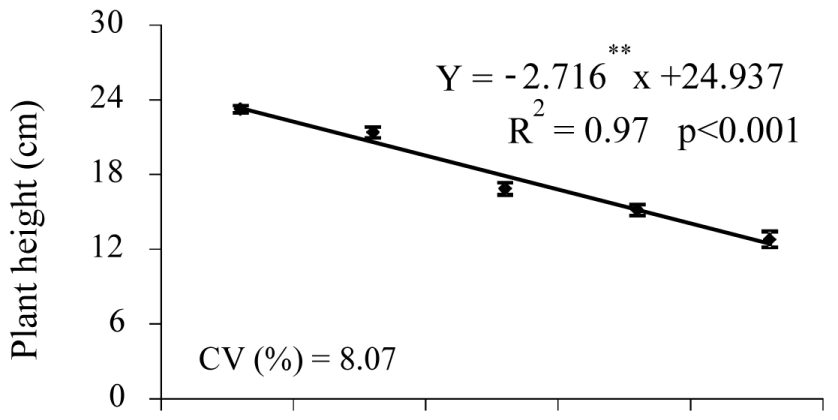

(a)

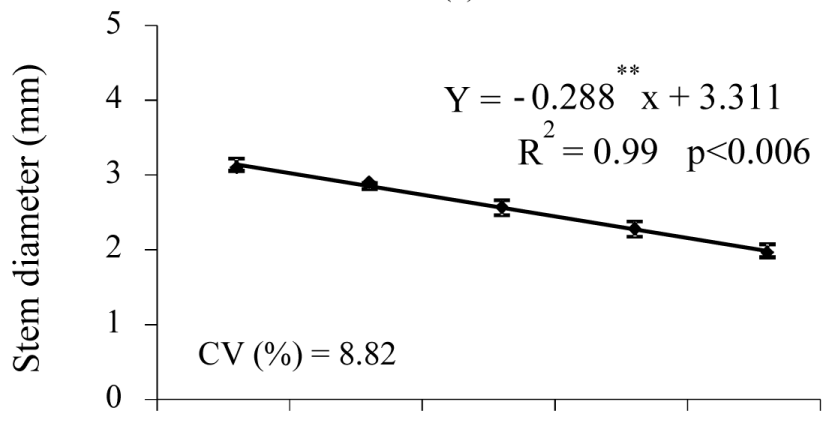

(b)

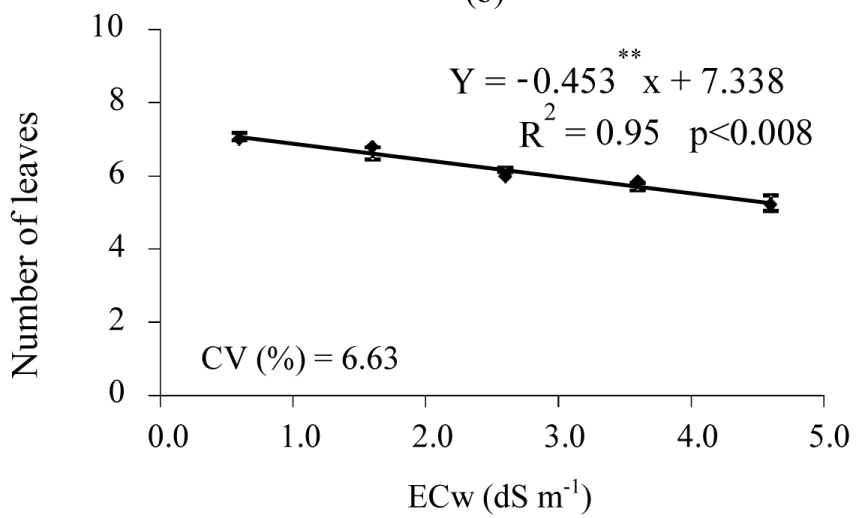

(c)

Figure 1. Plant height (a); stem diameter (b) and number of leaves (c) of sesame genotypes irrigated with saline water; ${ }^{*}=$ significant at $1 \%$ of probability; bars indicate the standard error of the mean $(n=4)$; CV $(\%)=$ Coefficient of variation. 
growth of sesame genotypes.

Contrary to the results of this study, in which salinity did not influence the germination and initial growth of the three genotypes, Abbasdokht et al. [9] reported a reduction in the growth of seedlings of 10 sesame varieties and identified two promising genotypes for plant breeding studies that focus on tolerance to saline stress.

\subsection{Experiment 2-Production Cycle}

By the analysis of variance of the data of this experiment, covering the entire plant cycle, the effect of salinity depended on the genotype, because for most variables the interaction was significant for these both factors, except for the number of leaves. According to the growth functions (Figure 2), the effect of saline stress was lower in comparison to the first experiment (Figure 1), which was restricted to the initial growth stage after seed germination.

A small influence of salinity on plant height (Figure 2) and stem diameter (Figure 3) was observed, although it had no influence on the number of leaves (Figure 4(a)). This can be explained by the fact that, in this experiment, saline water irrigation started when plants were already established, at 29 DAS, meaning that plant vegetative growth was affected by the salts. This fact can be an indication for farmers who own land with saline water that it can be used in the sesame production, provided that it is applied (irrigation without wetting the leaves, as adopted in the experiment) in the final two thirds of the plant cycle.

Plant height decreased by $3.08 \%$ for BRS Seda, 3.09\% for LAG-927561 and $3.91 \%$ for LAG-26514 (Figure 2), per unit increase of the irrigation water's electrical conductivity. Thus, plant height of the strain LAG-26514, referred to as Pretinha, was most harmed by salinity.

Sesame stem diameter (Figure 3) was negatively affected only for the variety BRS Seda, ranging from 11.20 to $10.35 \mathrm{~mm}$ between the salinity levels of 0.6 and $4.6 \mathrm{dS} \mathrm{m} \mathrm{m}^{-1}$, with a reduction of $0.2125 \mathrm{~mm}$ for each unit increase in ECw, representing a decrease of $1.88 \%$ per unit increase. In the genotypes LAG-

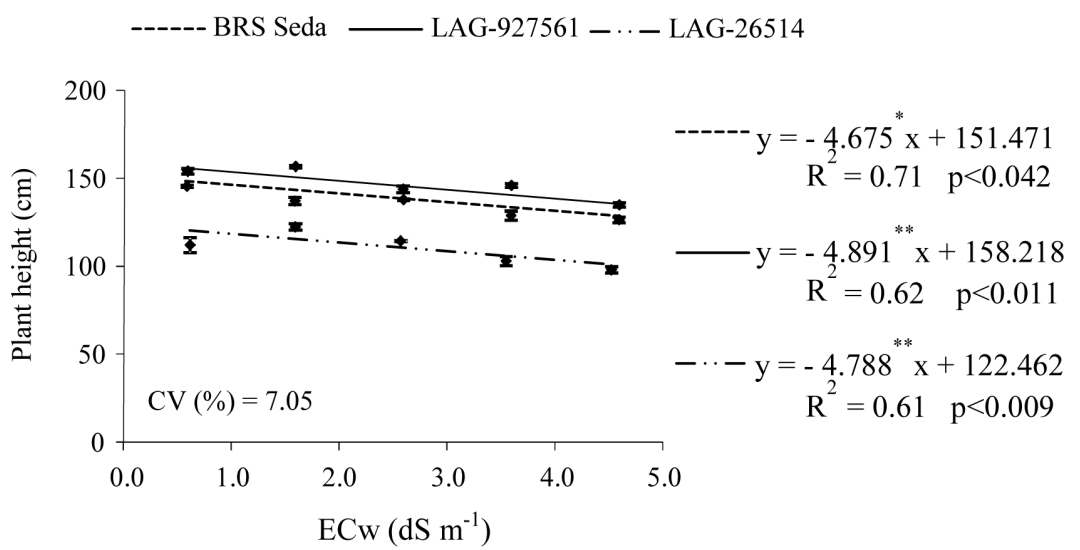

Figure 2. Plant height of sesame genotypes irrigated with saline water; ${ }^{\star}$ and ${ }^{\star *}=$ signifi- $^{*}$ cant at $5 \%$ and $1 \%$ of probability, respectively; bars indicate the standard error of the mean $(n=4)$; CV $(\%)=$ Coefficient of variation. 
BRS Seda LAG-92756 - - LAG-26514

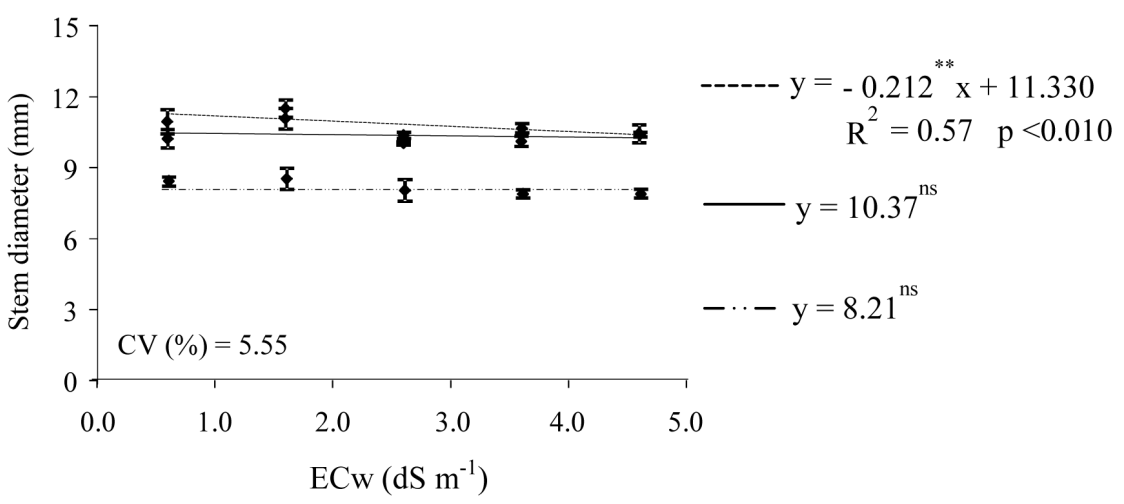

Figure 3. Stem diameter of sesame genotypes irrigated with saline water; ${ }^{*}=$ significant at $1 \%$ of probability; bars indicate the standard error of the mean $(n=4)$; CV $(\%)=$ Coefficient of variation.
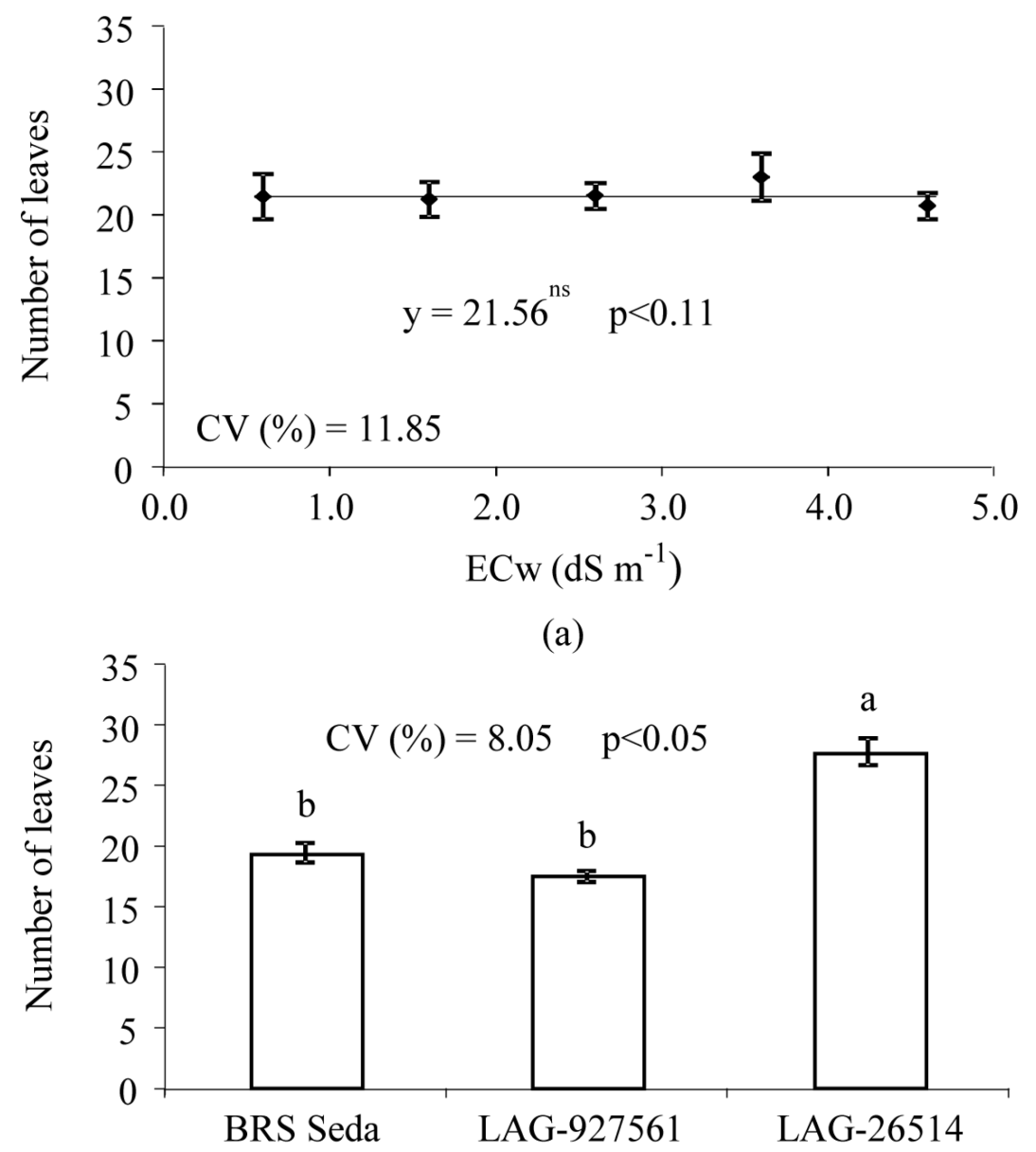

Sesame genotypes

(b)

Figure 4. Number of leaves: (a) means of the salinity (ECw) treatments and (b) means comparison test between genotypes. There is no difference between genotypes in columns with the same letter according to Tukey's test $(p<0.05)$; ns = not significant; bars indicate the standard error of the mean $(n=4) ; \mathrm{CV}=$ Coefficient of variation. 
927561 (mean value of $10.38 \mathrm{~mm}$ ) and LAG-26514 (8.22 mm), stem diameter was not compromised by the ECw levels of the irrigation water. For these two genotypes, plant height was affected more by saline stress, but there was no reduction in stem diameter, thus compensating for the effects on plant growth.

The number of leaves was not influenced by salinity levels in this study as a mean value of 21.56 leaves per plant (Figure $4(\mathrm{a})$ ) was seen. In the first experiment addressing the stages of plant germination and initial development, the salinity treatments affected leaf emergence, with a 0.45 decrease in leaves, that is, $6.17 \%$ per unit increase of ECw. This is more evidence of lower stress when saline water is used in the irrigation of sesame from 29 DAS onwards, as observed for height growth, compared with the negative effects of its use in the entire cycle, as observed by Mahmood et al. [12].

However, there were differences in leaf emergence between genotypes, with LAG-26514 (Pretinha) being superior (mean value of 27.76 for leaves-Figure $4(\mathrm{~b})$ ). It should be pointed out that this is a characteristic inherent to this genotype, which has a very different morphology, with a great number of lateral ramifications.

\subsection{Grain Production}

Sesame production components were also affected by the increase in water salinity, which varied with genotype.

The number of capsules per plant (NCP) ranged from 20.06 to 34.56 for BRS Seda, 18.76 to 36.23 for LAG-927561 and from 39.78 to 45.62 for LAG-26514; this latter was the genotype with the highest production, even in the treatment of $4.6 \mathrm{dS} \mathrm{m}^{-1}$, the highest salinity level (Figure 5). The strain LAG-927561 (Branquinha) was the most affected by salinity, with a decrease of 4.37 capsules per plant per unit increase of ECw. LAG-26514 (Pretinha) showed a decrease of only 1.46 capsules per plant.

For the highest salinity levels, abscission of flowers and capsules were observed, especially in the strain LAG-927561, but this also occurred in the other genotypes. The abscission of these reproductive structures was probably caused

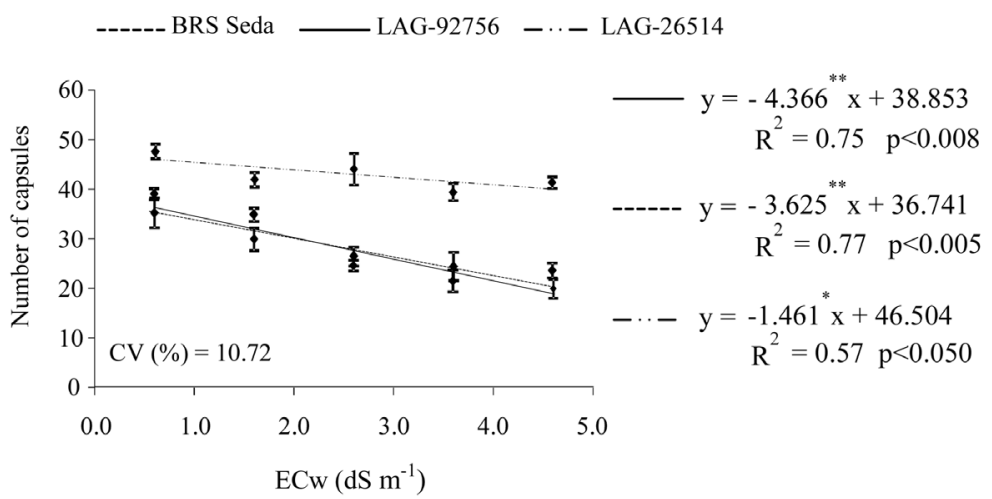

Figure 5. Number of capsules per plant in sesame genotypes irrigated with saline water. ${ }^{*}$ and ${ }^{* *}=$ significant at $5 \%$ and $1 \%$ of probability, respectively; bars indicate the standard error of the mean; $\mathrm{CV}=$ Coefficient of variation. 
by the abscisic acid, because the correlation between ABA synthesis in plants under saline stress and the fall of flowers and fruits is present in the literature [19]. The reduction in fruiting is consistent with the sesame results observed by Mahmood et al. [12].

The mass of seeds per plant (MSP-Figure 6) was more affected by salinity than the number of capsules (Figure 5), contrary to the results observed by Aghajari et al. [6] in an experiment carried out in Iran with two local cultivars of sesame. The highest reduction per unit increase of ECw (18.99\%) was observed for BRS Seda (Figure 6), while NCP decreased only $9.87 \%$ in the same variety. In the strain LAG-26514, despite the reduction in NCP (3.14\%), seed mass production decreased by $16.65 \%$ per unit increase of ECw. In the genotype LAG927561, the decrease in seed production was $14.61 \%$, while NCP decreased by $11.24 \%$ per unit increase of ECw. Despite the lower reduction in the weight of seeds per plant, the production of the genotype LAG-927561 (Branquinha) is low (Figure 6) compared with the others.

Considering as a reference the use of $1.6 \mathrm{dS} \mathrm{m}^{-1}$ water for the irrigation of the three sesame genotypes, which is common in the semi-arid region in Northeast Brazil, the production would be 5.46, 5.17 and $6.40 \mathrm{~g} \mathrm{plant}^{-1}$ for BRS Seda, LAG-927561 and LAG-26514, respectively. The highest individual production of capsules (number) and seeds (weight) of the strain LAG-26514, even with lower plant growth in height (Figure 2), was due to its branched growth, in which the photosynthetic capacity is also favored by the emergence of a higher number of leaves (Figure 4(b)).

Although plants were cultivated in recipients that had limited soil volume (20 $\mathrm{L})$, the estimated productions per unit of area when irrigating plants with $1.6 \mathrm{dS}$ $\mathrm{m}^{-1}$ water would be approximately 726,687 and $851 \mathrm{~kg} \cdot \mathrm{ha}^{-1}$ for the genotypes BRS Seda, LAG-927561 and LAG-26514, respectively, considering a plant density of 133,000 plants $\mathrm{ha}^{-1}$ (spacing used by family farmers: $1.20 \times 0.30 \times 0.10 \mathrm{~m}$ ). Compared with the mass of grains obtained by Aghajari et al. [6] under field conditions, thus not limited by the recipient volume, the productivity obtained

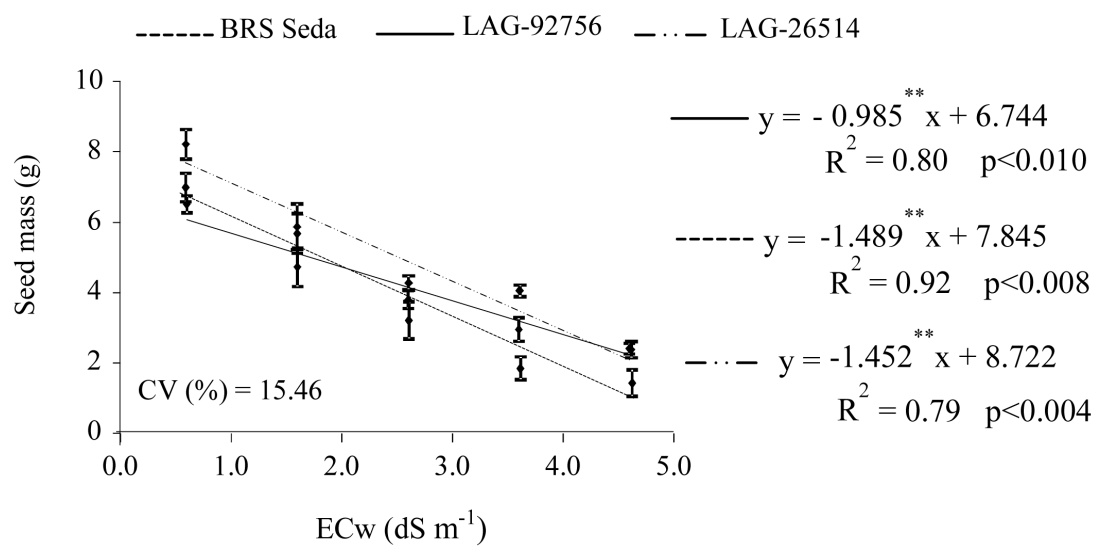

Figure 6. Mass of seeds per plant for sesame genotypes irrigated with saline waters. ${ }^{\star *}=$ significant at $1 \%$ of probability; bars indicate the standard error of the mean; CV = Coefficient of variation. 
in this study is high, considering that these authors obtained $710.9 \mathrm{~kg} \cdot \mathrm{ha}^{-1}$ with a local variety (spacing of $0.50 \times 0.10 \mathrm{~m}-200,000$ plants $\mathrm{a}^{-1}$ ) when irrigated with water of $2 \mathrm{dS} \mathrm{m} \mathrm{m}^{-1}$.

The weight of seeds per plant was more affected by salinity than the number of capsules per plant, contrary to the results observed by Aghajari et al. [6] and Mahmood et al. [12] when studying sesame genotypes in Iran.

\subsection{Relative Yield and Salt Tolerance}

In the classification of the genotypes with respect to salinity tolerance, according to the criterion of relative yield based on Veatch et al. [16], the three studied genotypes were sensitive to irrigation using water of $4.6 \mathrm{dS} \mathrm{m}^{-1}$, with reductions higher than $60 \%$ for the weight of seeds per plant (Table 2). BRS Seda is sensitive to salinity from $3.6 \mathrm{dS} \mathrm{m}^{-1}$ onwards, but the strains LAG-927561 and LAG26514 were classified as moderately tolerant until this ECw level and tolerant until $1.6 \mathrm{dS} \mathrm{m}^{-1}$.

In a study developed in Iran with two sesame cultivars, Aghajari et al. [6] observed similar results, with reductions in the relative yield of grains being higher than $66 \%$ when plants were irrigated with water of $5.0 \mathrm{dS} \mathrm{m}^{-1}$.

\subsection{Experiment 3-Phenological Stages}

In this experiment, in which salinity effects were evaluated at varying plant phenological stages, the interaction between factors was significant, that is, growth and production components varied according to the stage at which sesame genotypes were subjected to saline stress. This is expected for sesame [20] and other species [21] as sensitivity to salinity can vary between develop-

Table 2. Salinity tolerance classification for sesame genotypes through the criterion of relative reduction in weight of seeds per plant (RR) (\%) at each level of irrigation water electrical conductivity (ECw).

\begin{tabular}{|c|c|c|c|c|c|c|}
\hline Genotypes & $\mathrm{RR}(\%)$ & $\begin{array}{c}\text { Reduction } \\
\text { range }\end{array}$ & Classification & RR (\%) & $\begin{array}{c}\text { Reduction } \\
\text { range }\end{array}$ & Classification \\
\hline & \multicolumn{3}{|c|}{$\ldots \ldots \ldots \ldots \ldots \ldots$ ECw $1.6 \mathrm{dS} \mathrm{m}^{-1} \ldots \ldots \ldots \ldots \ldots$} & \multicolumn{3}{|c|}{$\ldots . . \mathrm{ECw} 2.6 \mathrm{dS} \mathrm{m}^{-1} \ldots \ldots \ldots \ldots \ldots$} \\
\hline BRS Seda & 21.42 & $21-40$ & MT & 42.85 & $41-60$ & MS \\
\hline $\begin{array}{l}\text { LAG-927561 } \\
\text { (Branquinha) }\end{array}$ & 16.01 & $<20$ & $\mathrm{~T}$ & 32.06 & $21-40$ & $\mathrm{MT}$ \\
\hline \multirow[t]{2}{*}{$\begin{array}{c}\text { LAG-26514 } \\
\text { (Pretinha) }\end{array}$} & 18.49 & $<20$ & $\mathrm{~T}$ & 36.99 & $21-40$ & MT \\
\hline & \multicolumn{3}{|c|}{ 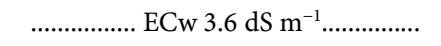 } & \multicolumn{3}{|c|}{$\ldots$ ECw $4.6 \mathrm{dS} \mathrm{m}^{-1} \ldots \ldots \ldots \ldots \ldots$} \\
\hline BRS Seda & 64.28 & $>60$ & S & 85.71 & $>60$ & $\mathrm{~S}$ \\
\hline $\begin{array}{l}\text { LAG-927561 } \\
\text { (Branquinha) }\end{array}$ & 48.05 & $41-60$ & MS & 64.07 & $>60$ & $\mathrm{~S}$ \\
\hline $\begin{array}{c}\text { LAG-26514 } \\
\text { (Pretinha) }\end{array}$ & 55.49 & $41-60$ & MS & 73.99 & $>60$ & $\mathrm{~S}$ \\
\hline
\end{tabular}

$\mathrm{T}=$ tolerant MT = moderately tolerant; $\mathrm{MS}=$ moderately sensitive $; \mathrm{S}=$ sensitive. 
ment stages.

In general, plant growth for the three genotypes was more affected by salinity when plants were irrigated with saline water in the vegetative stage (SS1) compared with the flowering/fruiting stage (SS2) (Figure 7). As an example, the growth in height of BRS Seda, when irrigated with saline water $\left(3.6 \mathrm{dS} \mathrm{m}^{-1}\right)$ in the reproductive stage, was higher than in plants subjected to this stress level during the vegetative stage (Figure $7(a)$ ). In the other variables, the values were not different when comparing stress in the reproductive stage (SS2) against the control treatment (without saline stress-SE) for the same genotype. A similar result also occurred with the strain LAG-927561 (Branquinha), differing only for the number of leaves (Figure $7(\mathrm{c})$ ).

In fact, for growth variables, the number of leaves was the most affected by salinity, differing when the three genotypes were irrigated with saline water in the

\section{BRS Seda $\quad \square$ LAG-927561 @LAG-26514}

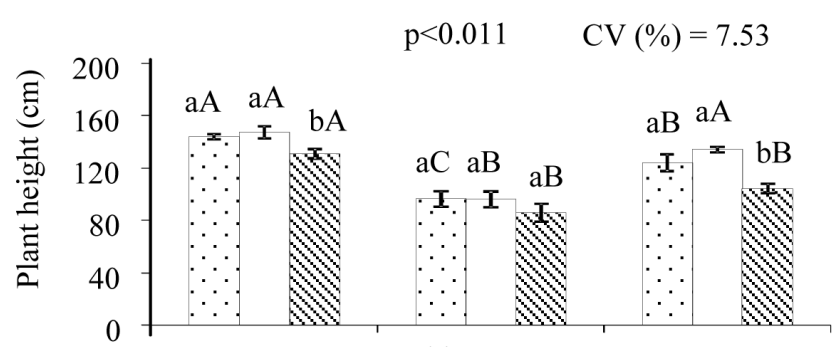

(a)

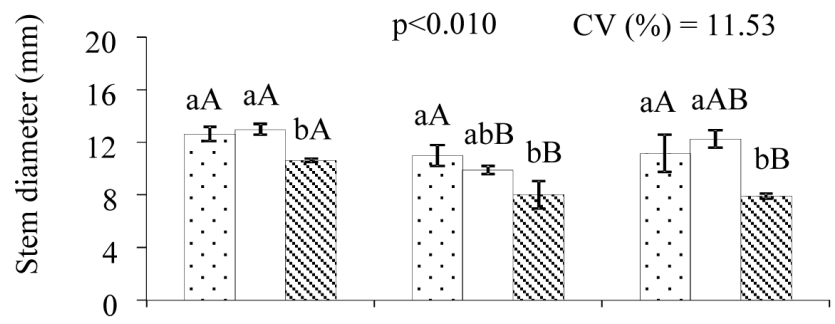

(b)

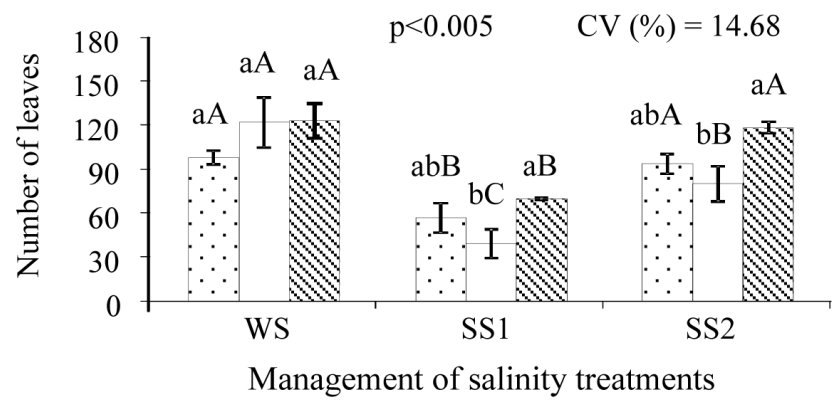

(c)

Figure 7. Plant height (a); stem diameter (b) and number of leaves (c) of sesame genotypes under saline stress applied in different development stages. The genotypes with the same lowercase have the same salinity management and there is no difference between the salinity treatments with the same capital letter for each genotype; bars indicate the standard error of the mean $(n=4)$; WS - plants without saline stress; $\mathrm{SS}_{1}$ - plants under saline stress during the vegetative stage; $\mathrm{SS}_{2}$ - plants under saline stress in the reproductive stage; $\mathrm{CV}=$ Coefficient of variation. 
vegetative stage. Thus, it is the most adequate variable to evaluate tolerance to saline stress. Considering the three genotypes, the strain LAG-927561 (Branquinha) is the most sensitive to saline stress during leaf emergence.

Plants from the strain LAG-26514 (Pretinha) tend to grow less in height and diameter compared with the other genotypes, but present a higher number of leaves, which was also observed in the previous experiment largely due to its branched growth (Figure 4(b)). When irrigated with saline water and varying the phenological stage of the plants, this genotype was the most affected with respect to plant height and stem diameter (Figure 7(a); Figure 7(b)).

Only one study was found on the application of saline stress in different stages of sesame growth [10], in which plants of seven genotypes were irrigated with saline water from 40 days after germination onwards. These authors found that plant height and number of leaves were affected by the treatments. At 40 DAS, plants must have been in the flowering/fruiting stage, which corresponds to the SS2 treatment of the present study, with similar results.

\subsection{Grain Production}

As for production, no difference was observed between the genotypes for the number of capsules per plant and mean weight of seeds per plant, considering the data obtained in each salinity management (Figure 8). Differences were observed for the treatments of saline stress management, with negative effects of salinity on both production variables. The production of seeds (MSP) was more affected than the number of capsules per plant when plants were irrigated with saline water $\left(3.6 \mathrm{dS} \mathrm{m}^{-1}\right)$ in the flowering/fruiting stage (SS2). The reduction in NCP for the strain Pretinha (LAG-26514), the least harmed by salinity, was $46.8 \%$ (Figure 8(a)) compared with the value obtained without stress (SE), but the decrease in the mass of seeds (MSP) was higher, about 67.3\% (Figure 8(b)). The strain Branquinha (LAG-927561) was the most affected by saline stress, both for NCP and MSP, with reductions of $69.4 \%$ and $81.9 \%$, respectively, in comparison to the low-salinity treatment (SE). According to Todaka et al.'s [22] study on rice, the reproductive stage is the most crucial, because it is related to seed production.

Comparing these production data (varying phenological stages) with those of the second experiment, in which plants were irrigated with saline water from 29 DAS until the end of the cycle, the productions of capsules and seeds were more affected. That is, the effects of salinity were less harmful to plant production when irrigated with saline water $\left(3.6 \mathrm{dS} \mathrm{m}^{-1}\right)$ starting at $29 \mathrm{DAS}$, even with the continuation until the end of the cycle. In this condition, saline stress was imposed at the end of the vegetative stage, precisely the stage of highest sensitivity to this stress, according to the results obtained in the third experiment, resulting in less damage to plants.

Similar studies with sesame or other species involving variations in more than one plant cultivation cycle were not found in the literature. For the variation of only the phenological stages in which plants were subjected to irrigation with saline water, there are studies on rice [22] and sorghum [23], which found 


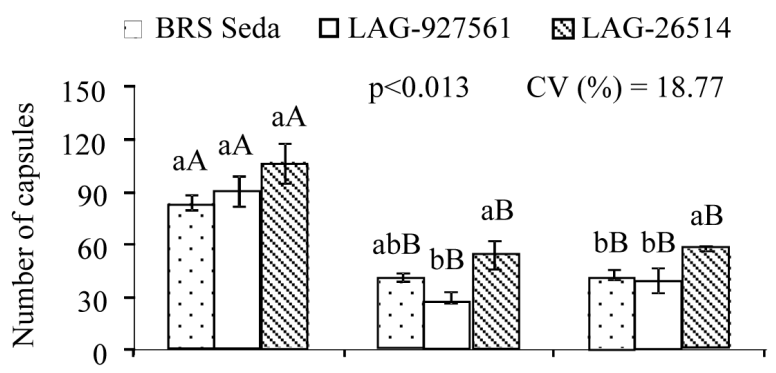

(a)

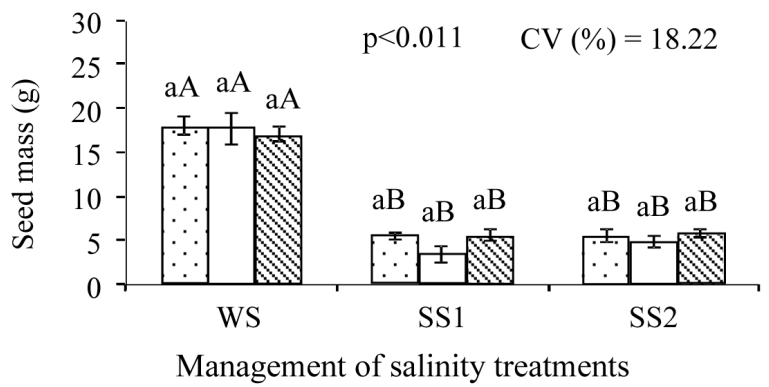

(b)

Figure 8. Number of capsules per plant (a) and mass of seeds (b) of sesame genotypes irrigated by saline waters in different development stages. The genotypes with the same lowercase have the same salinity management and there is no difference between the salinity treatments with the same capital letter in each genotype; bars indicate the standard error of the mean; WS-plants without saline stress; $\mathrm{SS}_{1}$ - plants under saline stress during the vegetative stage; $\mathrm{SS}_{2}$ - plants under saline stress in the reproductive stage; $\mathrm{CV}=$ Coefficient of variation.

differences in the tolerance to saline stress.

For sunflower, also varying the stages in which plants were irrigated with saline water, Morais et al. [24] did not observe a decrease in plant production when using water of $3.53 \mathrm{dS} \mathrm{m}^{-1}$, thus it can be used in the entire cycle. However, it should be pointed out that sunflower is classified as tolerant to salinity [25]. This is different to sesame for which the results in the literature are controversial.

\section{Conclusions}

- Irrigation water salinity does not interfere with germination and emergence speed of the three sesame genotypes, but affects seedling growth regardless of genotype.

- The number of leaves is the most adequate growth variable to evaluate sesame tolerance to salinity.

- Plant growth of the genotypes BRS Seda, LAG-927561 (Branquinha) and LAG-26514 (Pretinha) was more affected when saline stress was applied in the vegetative stage, compared with the flowering/fruiting stage.

- Sesame grain production is the most inhibited production component when saline stress is applied in both vegetative and production stages. The strains LAG-927561 and LAG-26514 are promising for studies on adaptation 
to saline stress.

\section{References}

[1] Kemal Ünal, M. and Yalçin, H. (2008) Composición de Semillas de Sésamo de Turquía y Caracterización de sus Aceites. Grasas y Aceites, 59, 23-26.

[2] Pathak, N., Rai, A,K., Kumarim, R., Thapa, A. and Bhat, K.V. (2014) Sesame Crop: An Underexploited Oilseed Holds Tremendous Potential for Enhanced Food Value. Agricultural Sciences, 5, 519-529. https://doi.org/10.4236/as.2014.56054

[3] Mkamilo, G.S. and Bedigian, D. (2007) Sesamum indicum L. Plant Resources of Tropical Africa, 14, 153-158.

[4] Antoniassi, R., Arriel, N.H.C., Gonçalves, E.B., Freitas, S.C., Zanotto, D.L. and Bizzo, H.R. (2013) Effect of Cultivation Conditions on the Composition of Sesame Seed and Oil. Revista Ceres, 60, 301-310. https://doi.org/10.1590/S0034-737X2013000300001

[5] Uçan, K. and Killi, F. (2010) Effects of Different Irrigation Programs on Flower and Capsule Numbers and Shedding Percentage of Sesame. Agricultural Water Management, 96, 227-233. https://doi.org/10.1016/j.agwat.2010.08.005

[6] Aghajari, S., Boroomand-Nasab, S., Sakinejad, T., Behmanesh, M. and Motamedi, B. (2014) Sesame (Sesamum indicum L.) Performance under Different Salinity Levels of Water. Researcher, 6, 21-24.

[7] Joshi, S.V., Panchal, N.S. (2014) Effect of Supplemental Calcium on NaCl-stressed Sesamum indicum. Bionano Frontier, 17, 93-96.

[8] Zhu, M., Shabala, S., Shabala, L., Fan, Y. and Zhou, M.X. (2014) Evaluating Predictive Values of Various Physiological Indices for Salinity Stress Tolerance in Wheat. Journal of Agronomy and Crop Science, 201, 115-124. https://doi.org/10.1111/jac.12122

[9] Abbasdokht, H., Ashrafi, E. and Taheri, S. (2012) Effects of Different Salt Levels on Germination and Seedling Growth of Sesame (Sesamum indicum L.) Cultivars. Tech. J. Eng. and Appl. Sci., 2, 309-313.

[10] Bazrafshan, A.H. and Ehsanzadeh, P. (2014) Growth, Photosynthesis and Ion Balance of Sesame (Sesamum indicum L.) Genotypes in Response to $\mathrm{NaCl}$ Concentration in Hydroponic Solutions. Photosynthetica, 52, 134-147.

https://doi.org/10.1007/s11099-014-0015-z

[11] Bahrami, H. and Razmjoo, J. (2012) Effect of Salinity Stress (NaCl) on Germination and Early Seedling Growth of Ten Sesame Cultivars (Sesamum indicum L.). International Journal of AgriScience, 2, 529-537.

[12] Mahmood, S., Iran, S. and Athar, H.R. (2003) Intra-Specific Variability in Sesame (Sesamum indicum L.) for Various Quantitative and Qualitative Attributes under Differential Salt Regimes. Journal of Research Science, 14, 177-186.

[13] Peel, M.C., Finlayson, B.L. and Mcmahon, T.A. (2007) Updated World Map of the Koppen-Geiger Climate Classification. Hydrology and Earth System Sciences, 11, 1633-1644. https://doi.org/10.5194/hess-11-1633-2007

[14] Suassuna, J. and Audry, P. (1993) Statistics on Irrigation Waters Salinity in the Brazilian Semiarid Northeast. Fundação Joaquim Nabuco, Recife, 35.

[15] Ranal, M.A. and Santana, D.G. (2006) How and Why to Measure the Germination Process? Brazilian Journal of Botany, 29, 1-11. https://doi.org/10.1590/S0100-84042006000100002

[16] Veatch, M.E., Smith, S.E. and Vandemark, G. (2004) Shoot Biomass Production 
among Accessions of Medicago truncatula Exposed to NaCl. Crop Science, 44, 1008-1013. https://doi.org/10.2135/cropsci2004.1008

[17] Mize, C.W. and Schultz, R.C. (1985) Comparing Treatment Means Correctly and Appropriately. Canadian Journal of Forest Research, 15, 1142-1148.

https://doi.org/10.1139/x85-185

[18] Azevedo, M.R.Q.A., Almeida, F.A.C., Gouveia, J.P.G., Azevedo, C.A.V., Silva, M.M. and Pordeus, R.V. (2003) Germination and Vigour in the Initial Development of Sesame: Effect of Irrigation Water Salinity. Brazilian Journal of Agro-Industrial Products, 5, 167-172.

[19] Lin, F., Jensen, C.R. and Andersen, M.N. (2004) Drought Stress Effect on Carbohydrate Concentration in Soybean Leaves and Pods during Early Reproduction Development: Its Implication in Altering Pod Set. Field Crops Research, 86, 1-13. https://doi.org/10.1016/S0378-4290(03)00165-5

[20] Fazeli, K., Nezami, A., Parsa, M. and Kafi, M. (2012) Screening of Sesame Ecotypes (Sesamum indicum L.) for Salinity Tolerance under Field Conditions: 1-Phenological and Morphological Characteristics. Agroecology, 4, 20-32.

[21] Deinlein, U., Stephan, A.B., Horie, T., Luo, W., Xu, G. and Schroeder, J.I. (2014) Plant Salt-Tolerance Mechanisms. Trends in Plant Sciences, 19, 371-379.

https://doi.org/10.1016/j.tplants.2014.02.001

[22] Todaka, D., Nakashima, K., Shinozaki, K. and Yamaguchi-Shinozaki, K. (2012) Toward Understanding Transcriptional Regulatory Networks in Abiotic Stress Responses and Tolerance in Rice. Rice, 5, 1-9. https://doi.org/10.1186/1939-8433-5-6

[23] Kafi, M., Shariat, J.M.H. and Moayedi, A. (2013) The Sensitivity of Grain Sorghum (Sorghum bicolor L.) Developmental Stages to Salinity Stress: An Integrated Approach. Journal of Agricultural Science and Technology, 15, 723-736.

[24] Morais, F.A., Gurgel, M.T., Oliveira, F.H.T. and Mota, A.F. (2011) Influence of Irrigation with Saline Water on Sunflower. Revista Ciência Agronômica, 42, 327-336. https://doi.org/10.1590/S1806-66902011000200010

[25] Katerji, N., Van, H.J.W., Hamdy, A. and Mastrorilli, M. (2000) Salt Tolerance Classification of Crops According to Soil Salinity and to Water Stress Day Index. Agricultural Water Management, 43, 99-109. https://doi.org/10.1016/S0378-3774(99)00048-7

\section{Submit or recommend next manuscript to SCIRP and we will provide best} service for you:

Accepting pre-submission inquiries through Email, Facebook, LinkedIn, Twitter, etc. A wide selection of journals (inclusive of 9 subjects, more than 200 journals)

Providing 24-hour high-quality service

User-friendly online submission system

Fair and swift peer-review system

Efficient typesetting and proofreading procedure

Display of the result of downloads and visits, as well as the number of cited articles

Maximum dissemination of your research work

Submit your manuscript at: http://papersubmission.scirp.org/

Or contact ajps@scirp.org 